\section{Clinical and Molecular Genetics of Primary Pigmented Nodular Adrenocortical Disease}

\begin{abstract}
Carney complex (CNC) is a multiple endocrine neoplasia (MEN) syndrome associated with other, non-endocrine manifestations such as lentigines, cardiac myxomas and schwannomas. Primary pigmented nodular adrenocortical disease (PPNAD), leading to corticotrophin-independent Cushing's syndrome is the most frequent endocrine lesion in CNC. The complex has been mapped to 2 p16 and 17q22-24, although additional heterogeneity may exist. The gene coding for the protein kinase $A$ (PKA) type l-a regulatory subunit (Rla), PRKARIA, had been mapped to 17q. Cloning of the PRKARIA genomic structure and its sequencing showed mutations in CNC-, CNC with PPNAD- and sporadic PPNAD-patients. In CNC tumors, PKA activity showed increased stimulation by CAMP, whereas PKA activity ratio was decreased, and in CNC tumors, there is $\mathrm{LOH}$ of the normal allele, suggesting that normal PRKARIA may be a tumor suppressor in these tissues. CNC is the first human disease caused by mutations of one of the subunits of the PKA enzyme, a critical component of the cAMP signaling system and a potential participant in many other signaling pathways. (Arq Bras Endocrinol Metab 2004;48/5:637-641)
\end{abstract}

Keyword: Carney complex; Primary pigmented nodular adrenocortical disease; PRKARIA

\section{RESUMO}

Clínica e Genética Molecular da Doença Nodular Adrenocortical Pigmentada Primária.

Complexo de Carney (CNC) é uma síndrome de neoplasia endócrina múltipla (MEN) associada com outras manifestaçōes não endócrinas, como lentígenes, cardiomixomas e adenomas de células de Schwann. A doença nodular pigmentada primária da adrenal (PPNAD), que apresenta-se como síndrome de Cushing independente de corticotropina é a lesão mais freqüente observada em CNC. O CNC tem sido relacionados aos sítios cromossômicos 2p16 e 17q22-24, entretanto, heterogenicidade pode ocorrer. O gene codificador da proteína reguladora tipo $1 \mathrm{~A}$ da proteína quinase $A(R / a)$, PRKARIA, tem sido localizado no cromossomo 17q. A clonagem da estrutura genômica e seqüenciamento do gene PRKAR1A revelou mutações em pacientes com CNC e em formas esporádicas de PPNAD. Em tumores de pacientes com CNC, a proteína quinase A apresenta uma resposta de atividade maior após o estímulo com AMPc. Também, nestes tecidos, é observada a perda de heterozigose do alelo normal. Isto sugere que o gene normal do PRKARIA pode funcionar como um gene de supressão tumoral nos tecidos estudados. CNC é a primeira doença conhecida a ocorrer devido a mutações de uma das sub-unidades da proteína quinase $A$, um componente crucial na via de sinalização do AMPc e um potencial participante de outras vias de sinalização celular. (Arq Bras Endocrinol Metab 2004;48/5:637-641)

Descritores: Complexo de Carney; Doença nodular pigmentada primária da adrenal; PRKARIA

\section{atualização}

\author{
Fabiano Sandrini \\ Constantine Stratakis
}

Section on Endocrinology \& Genetics (SEGEN), Developmental Endocrinology Branch, National Institute of Child Health and Human Development, Bethesda, MD 20892-1862, USA.

Recebido em 20/07/04 Aceito em 30/07/04 
$\mathrm{P}$ RIMARY PIGMENTED NODULAR ADRENOCORTICAL DISEASE (PPNAD) is a rare cause of ACTH-independent Cushing's syndrome (CS) caused by autonomously functioning nodules of the adrenals. PPNAD is associated with Carney complex (CNC) (1), a multiple neoplasia syndrome; occasionally it may present as a sporadic and isolated disorder. The recent molecular elucidation of CNC (2) allowed the generation of new hypotheses for PPNAD tumorigenesis. In this paper, we are going to review the PPNAD and its involvement in CNC.

CNC (OMIM 160980) (3) is a multiple neoplasia syndrome, inherited in an autosomal dominant manner, characterized by lentigines, cardiac myxomas, and endocrine tumors as PPNAD, large-cell calcifying Sertoli cell tumor (LCCSCT), GH-producing adenoma and thyroid carcinomas. CNC has been considered a multiple endocrine neoplasia syndrome because most CNC patients have more than one endocrine tumor $(4,5)$. PPNAD is the most frequent and characteristic endocrine tumor observed in CNC (1). CNC is frequently observed in families (6); however, approximately $50 \%$ of the cases are without any family history $(7,8)$. Two syndromes that had previously been described as LAMB (lentigines, atrial myxomas and blue nevi) (9) or NAME (nevi, atrial myxomas and ephelides) (10), represented variants of CNC $(6,11)$.

Diagnostic criteria for CNC (table 1 ) have been reviewed recently (6). The presence of 2 (or more than 2 ) of the following manifestations, spotty skin pigmentation, cutaneous or mucosal myxoma, cardiac myxoma, breast myxoma, PPNAD, GH-producing adenoma, primarily large-cell calcifying Sertoli cell tumor (LCCSCT), thyroid carcinoma, psammomatous melanotic schwannoma, blue nevus, breast ductal adenoma and/or osteochondromyxoma, makes the diagnosis of CNC.

More than $25 \%$ of $\mathrm{CNC}$ patients present with manifestations of PPNAD. Even this number is probably an underestimate: PPNAD was observed in almost all CNC patients who underwent to autopsy (6). PPNAD involves both adrenal glands. The adrenals are usually normal in size but contain several dark brown micro-nodules (12). These nodules are non-encapsulated and the surrounding cortex is normal, atrophic or even hypertesrophic $(13,14)$. In PPNAD from CNC patients, the nodular cells stain positively for synaptophysin by immunohistochemistry. This neuroendocrine marker, which in normal glands is prent only in medullary cells, suggest a neuroendocrine role in PPNAD development or de-differentiation of adrenocortical cells in PPNAD. Other neuroendocrine mark- ers such as chromogranin A and tyrosine hydroxylase do not stain PPNAD nodules (15).

PPNAD occurs isolated, but than $90 \%$ of all cases are associated with CNC (16). Familial cases of isolated PPNAD have also been reported (2). These families had no other clinical feature, which could have suggested CNC; however, subtle manifestations of the disorder could have been missed $(17,18)$. A minority of PPNAD patients present during the first 2-3 $\mathrm{yr}$, whereas the majority manifest in the second and third decade of life (6).

PPNAD is a non-malignant lesion; however, surgery is indicated because the mortality among patients with PPNAD is the same as those associated with Cushing's syndrome (CS) (6). Patients with PPNAD should be followed by screening for CNC and its potentially fatal components $(13,19)$. Clinically, patients with PPNAD may present with signs of classic CS (moon face, central obesity, hypertension, myopathy); however, other patients present with atypical signs of cyclical or subtle hypercortisolism and no real stigmata of CS. These patients may have osteopenia, osteoporosis, mood or psychiatric changes and are difficult to diagnose $(20,21)$.

Liddle's test is the most accurate test for the diagnosis of PPNAD. An increase in urinary free cortisol excretion of more than $50 \%$ on day 6 of the test identifies almost all CNC patients with PPNAD. This paradoxical response is rarely observed in patients with other primary adrenal diseases (21). It has been suggested that this phenomenon of increasing cortisol excretion in PPNAD under dexamethasone stimulation is related to the primary lesion; in other words, it is not associated with unusual responses of the hypothalamic-pituitary axis. This paradoxical response was observed in vitro with PPNAD tissues and was correlated with increased glucocorticoid receptor expression (22).

Two genetic loci have been identified for $\mathrm{CNC}$, on chromosome $2 \mathrm{pl} 6(23,24)$ and chromosome 17q22-24 (25). This second locus harbors the gene encoding the regulatory subunit alpha of the protein kinase $A$ (PRKARlA), which has recently shown to be mutated in CNC patients $(26,27)$. The gene located on chromosome region 2 pl6 is still unknown. There is no clear genotypephenotype correlation among patients with CNC. This was well demonstrated when 2 families sharing the same mutation presented with clearly different clinical manifestations (26). Cytogenetic studies in tumor tissues from $\mathrm{CNC}$ patients revealed the involvement of chromosome $2 \mathrm{pl} 6$ even in patients who mapped to chromosome 17q22-24 (28). 
The regulatory subunit type 1 alpha $(\mathrm{RI} \alpha)$ is involved in the protein kinase A (PKA) activity. PKA is the main mediator of cAMP signaling in mammals (29). PKA is a serine-threonine kinase and under hormone stimuli it promotes phosphorylation and plays a role in various cellular functions as DNA replication, cell division and cellular metabolism (30-32). There are four different regulatory subunits with tissue-specificity for 2 of them; RI? s the most abundant one with little, if any, tissue specificity. The PKA tetramer is, in fact, composed of two homodimers, one that contains two regulatory subunits and another that contains two catalytic subunits (29) (figure 1). The four genes that code for the various PKA regulatory subunits are grouped into two types, type I and type II. These define the two main isoforms of PKA, which were identified and named after their order of elution in chromatography (23). When cAMP molecule binds to the regulatory subunits, the PKA tetramer is dissolved in the dimmer of the regulatory subunits and the catalytic subunits. The latter phosphorylate nuclear and cytoplasmatic targets following their release from the tetramer (34). Type I PKA enzymes contain either regulatory subunit Ia or Ib; type II PKA enzymes contain either subunit IIa or IIb (35). Heterodimers may also form, but infrequently. In vitro, and in basal states, the catalytic subunits bind preferentially to regulatory subunits type II; type I subunits are favored in stimulated states (36).

The PRKARIA gene has been considered a potential oncogene due to the observation of its high expression in several tumors and tumor-derived cell lines $(37,38)$. In addition, downregulation of the PRKARIA gene by antisense oligonucleotides leads to growth inhibition in human cancer cells (39). Overexpression of the PKA type I isoform interacts with activated epidermal growth factor receptor (EGF-R) and stimulates growth and proliferation through the mitogen activated protein kinase (MAPK) (40). It is known that under normal growth, the cAMP/PKA pathway is required for phosphorylation of the tyrosine kinase Src that, after activating Rapl and blocking the activation of Raf- 1 by Ras, inhibits cell proliferation (4l). The PKA pathway activation by forskolin in $\mathrm{CD} 10+\mathrm{B}$ cell induces apoptosis and also decreases the expression of $\mathrm{Mcl}-1$, an anti-apoptotic $\mathrm{Bcl}$ family member (42). Interestingly, the PRKARIA gene was seen to be acting as a tumor suppressor gene in CNC: loss of heterozygosity is seen for the polymorphic markers within and surrounding the PRKARIA gene in lesions from CNC patients (2).

The PRKARlA gene is composed of 12 exons $(1 \mathrm{~A}, 1 \mathrm{~B}, 2,3,4 \mathrm{~A}, 4 \mathrm{~B}, 5,6,7,8,9$ and 10$)$ and the start codon is located at the exon 2. Mutations in
CNC patients are observed throughout the gene. There is high de novo incidence (27.3\% of kindreds) of the 578delTG mutation (in exon $4 \mathrm{~B}$ ); followed by mutations in exons 2 and 6 (26). The "hot spot" in exon $4 \mathrm{~B}$ may be explained by the presence of a TG repeat, which may lead to DNA polymerase "stuttering". Almost all mutations observed in CNC patients, lead to a premature stop codon and, consequently, result in a truncated regulatory 1 alpha subunit (RlA) protein $(2,26)$. This abnormal $\mathrm{Rla}$ protein is not detected in CNC mutant patients (26), because the non-sense mRNA is degraded by the mechanism of nonsense mRNA decay (43). Thus, all mutations are functionally equivalent. They result in increased PKA activity (2); heterozygosity in CNC patients supports the notion that mutations of the regulatory subunits act in a dominant fashion (44).

Further studies have shown a shift between PKA type I and type II in Epstein Barr virus immortalizedtransformed cells from CNC lymphocytes and also in a PPNAD from a CNC patient with a PRKARIA mutation (45). Cell lines from CNC patients containing the PRKARlA gene mutation showed increased ERKl/2 phosphorylation that was associated with increased cell proliferation. Thus, reversal of the usual PKA-mediated inhibition of a MAPK pathway in CNC cells may contribute to tumorigenesis (46).

In a PPNAD tissue (with PRKARIA mutation) a higher level of CREB phosphorylation was seen (47). Immunostaining of PPNAD tissue with the PKA subunits revealed that in the mutated tissue, there is an irregular distribution of the subunits and lower amount of subunit RlA in the nodules (47). It was suggested that PRKARlA might behave not as a classic tumor suppressor gene; over-expression of PRKARIA and the other PKA subunits may be present in non-nodular tissue of mutated tumors and, thus, perhaps, precede nodular formation, underlining the complex way with which cAMP controls growth.

PRKARIA gene mutations and $17 \mathrm{q} \mathrm{LOH}$ were also observed in sporadic adrenocortical tumors; $\mathrm{LOH}$ was more frequently observed in adrenal malignancies than adenomas (48). Other abnormalities in the PKA pathway, as the loss of cAMP response element binding protein (CREB) expression has also been observed in adrenal carcinomas (49). The same pattern of higher LOH of $17 \mathrm{q}$ markers in malignant lesions was observed among thyroid tumors (50), but this feature was not seen with high frequency in pituitary adenomas (5l). Higher activity of the PKA has also been shown to promote malignancy in other tissues, including breast tissue $(52)$. 
The second locus at $2 \mathrm{pl} 16$ is currently under study. However, this specific region is not completely sequenced by the Human Genome Project. Other loci are also being investigated; however, $2 \mathrm{pl}$ appears to be a significant locus for sporadic adrenal tumors, too (53).

\section{REFERENCES}

1. Carney JA, Gordon H, Carpenter PC, Shenoy BV, Go VL. The complex of myxomas, spotty pigmentation, and endocrine overactivity. Medicine (Baltimore) 1985;64: 270-83.

2. Kirschner LS, Carney JA, Pack SD, Taymans SE, Giatzakis $\mathrm{C}$, Cho YS, et al. Mutations of the gene encoding the protein kinase A type l-alpha regulatory subunit in patients with the Carney complex. Nat Genet 2000;26: 89-92.

3. OMIM. Online Mendelian Inheritance in Man. Center for Medical Genetics, Johns Hopkins University and National Center for Biotechnology Information, National Library of Medicine 2002.

4. Stratakis CA, Kirschner LS, Carney JA. Carney complex: diagnosis and management of the complex of spotty skin pigmentation, myxomas, endocrine overactivity, and schwannomas. Am J Med Genet 1998;80:183-5.

5. Marsh D, Zori R. Genetic insights into familial cancers update and recent discoveries. Cancer Lett 2002;181: 125-64.

6. Stratakis CA, Kirschner LS, Carney JA. Clinical and molecular features of the Carney complex: diagnostic criteria and recommendations for patient evaluation. J Clin Endocrinol Metab 2001;86:4041-6.

7. Akbas H, Kirali K, Daglar B, Kutay V, Isik O, Yakut C. Surgical treatment of left-atrial myxoma in Carney's complex. Thorac Cardiovasc Surg 1997;45:148-50.

8. Cheung PS, Thompson NW. Carney's complex of primary pigmented nodular adrenocortical disease and pigmentous and myxomatous lesions. Surg Gynecol Obstet 1989;168:413-6.

9. Rhodes AR, Silverman RA, Harrist TJ, Perez-Atayde AR. Mucocutaneous lentigines, cardiomucocutaneous myxomas, and multiple blue nevi: the "LAMB" syndrome. J Am Acad Dermatol 1984; 10:72-82.

10. Atherton DJ, Pitcher DW, Wells RS, MacDonald DM. A syndrome of various cutaneous pigmented lesions, myxoid neurofibromata and atrial myxoma: the NAME syndrome. Br J Dermatol 1980;103:42 1-9.

11. Stratakis CA. Genetics of Carney complex and related familial lentiginoses, and other multiple tumor syndromes. Front Biosci 2000;5:D353-D366.

12. Lack EE. Adrenal cortical nodules and tumor-like lesions. In.: Lack EE. Tumors of adrenal gland and extra-adrenal paraganglia. AFIP Fascicle No. 19, 3rd Series. American Registry of Pathology, Washington D.C. 1997.

13. Carney JA, Young WF Jr. Primary pigmented nodular adrenocortical disease and its associated conditions. Endocrinologist 1992;2:6-21.

14. Travis WD, Tsokos M, Doppman JL, Nieman L, Chrousos GP, Cutler GB Jr, et al. Primary pigmented nodular adrenocortical disease. A light and electron microscopic study of eight cases. Am J Surg Pathol 1989;13:921-30.

15. Stratakis CA, Carney JA, Kirschner LS, Willenberg HS, Brauer S, Ehrhart-Bornstein M, et al. Synaptophysin immunoreactivity in primary pigmented nodular adrenocortical disease: neuroendocrine properties of tumors associated with Carney complex. J Clin Endocrinol Metab 1999;84:1122-8.

16. Kirschner LS, Taymans SE, Stratakis CA. Characterization of the adrenal gland pathology of Carney complex, and molecular genetics of the disease. Endocr Res 1998;24:863-4

17. Armstrong DK, Irvine AD, Handley JM, Walsh MY, Hadden DR, Bingham EA. Carney complex: report of a kindred with predominantly cutaneous manifestations. Br J Dermatol 1997;136:578-82.

18. Liebler GA, Magovern GJ, Park SB, Cushing WJ, Begg FR, Joyner CR. Familial myxomas in four siblings. J Thorac Cardiovasc Surg 1976;71:605-8.

19. Stratakis CA, Carney JA, Lin JP, Papanicolaou DA, Karl $\mathrm{M}$, Kastner DL, et al. Carney complex, a familial multiple neoplasia and lentiginosis syndrome. Analysis of $11 \mathrm{kin}-$ dreds and linkage to the short arm of chromosome 2. J Clin Invest 1996;97:699-705.

20. Sarlis NJ, Chrousos GP, Doppman JL, Carney JA, Stratakis CA. Primary pigmented nodular adrenocortical disease: reevaluation of a patient with Carney complex 27 years after unilateral adrenalectomy. J Clin Endocrinol Metab 1997;82:1274-8.

21. Stratakis CA, Sarlis N, Kirschner LS, Carney JA, Doppman $\mathrm{JL}$, Nieman LK, et al. Paradoxical response to dexamethasone in the diagnosis of primary pigmented nodular adrenocortical disease. Ann Intern Med 1999; 131:585-91.

22. Bourdeau I, Lacroix A, Schurch W, Caron P, Antakly T, Stratakis CA. Primary pigmented nodular adrenocortical disease: paradoxical responses of cortisol secretion to dexamethasone occur in vitro and are associated with increased expression of the glucocorticoid receptor. J Clin Endocrinol Metab 2003;88:3931-7.

23. Stratakis CA, Jenkins RB, Pras E, Mitsiadis CS, Raff SB, Stalboerger $P G$, et al. Cytogenetic and microsatellite alterations in tumors from patients with the syndrome of myxomas, spotty skin pigmentation, and endocrine overactivity (Carney complex). J Clin Endocrinol Metab 1996; 81:3607-14.

24. Taymans SE, Kirschner LS, Giatzakis C, Stratakis CA. Radiation hybrid mapping of chromosomal region $2 \mathrm{p} 15$ p16: integration of expressed and polymorphic sequences maps at the Carney complex (CNC) and Doyne honeycomb retinal dystrophy (DHRD) loci. Genomics 1999; 56:344-9.

25. Casey M, Mah C, Merliss AD, Kirschner LS, Taymans SE, Denio $\mathrm{AE}$, et al. Identification of a novel genetic locus for familial cardiac myxomas and Carney complex. Circulation 1998;98:2560-6.

26. Kirschner LS, Sandrini F, Monbo J, Lin JP, Carney JA, Stratakis CA. Genetic heterogeneity and spectrum of mutations of the PRKARIA gene in patients with the Carney complex. Hum Mol Genet 2000;9:3037-46. 
27. Casey M, Vaughan CJ, He J, Hatcher CJ, Winter JM, Weremowicz S, et al. Mutations in the protein kinase A Rlalpha regulatory subunit cause familial cardiac myxomas and Carney complex. J Clin Invest 2000;106: R31-R38.

28. Matyakhina L, Pack S, Kirschner LS, Pak E, Mannan P, Jaikumar J, et al. Chromosome 2 (2p16) abnormalities in Carney complex tumours. J Med Genet 2003;40:268-77.

29. Krebs EG, Beavo JA. Phosphorylation-dephosphorylation of enzymes. Ann Rev Biochem 1979;48:923-59.

30. Francis SH, Corbin JD. Structure and function of cyclic nucleotide-dependent protein kinases. Ann Rev Physiol 1994;56:237-72.

31. Beebe SJ. The CAMP-dependent protein kinases and CAMP signal transduction. Semin Cancer Biol 1994:5: 285-94.

32. Costanzo V, Avvedimento EV, Gottesman ME, Gautier J, Grieco D. Protein kinase A is required for chromosomal DNA replication. Curr Biol 1999;9:903-6.

33. Reimann EM, Walsh DA, Krebs EG. Purification and properties of rabbit skeletal muscle adenosine $3^{\prime}, 5^{\prime}$ monophosphate-dependent protein kinases. J Biol Chem 1971;246:1986-95.

34. Montminy M. Transcriptional regulation by cyclic AMP. Ann Rev Biochem 1997;66:807-22.

35. Clegg CH, Cadd GG, McKnight GS. Genetic characterization of a brain-specific form of the type I regulatory subunit of CAMP-dependent protein kinase. Proc Natl Acad Sci USA 1988;85:3703-7.

36. McKnight GS, Cadd GG, Clegg CH, Otten AD, Correll LA. Expression of wild type and mutant subunits of the cAMP-dependent protein kinase. Cold Spring Harb Symp Quant Biol 1988;53 Pt 1:111-9.

37. Bold RJ, Alpard S, Ishizuka J, Townsend CM Jr, Thompson JC. Growth-regulatory effect of gastrin on human colon cancer cell lines is determined by protein kinase a isoform content. Regul Pept 1994;53:61-70.

38. Young MR, Montpetit M, Lozano Y, Djordjevic A, Devata $S$, Matthews JP, et al. Regulation of Lewis lung carcinoma invasion and metastasis by protein kinase A. Int $\mathbf{J}$ Cancer 1995;61:104-9.

39. Cho-Chung YS, Clair T, Tagliaferri P, Ally S, Katsaros D, Tortora $G$, et al. Site-selective cyclic AMP analogs as new biological tools in growth control, differentiation, and proto-oncogene regulation. Cancer Invest 1989;7:161-77.

40. Tortora G, Damiano V, Bianco C, Baldassarre G, Bianco $A R$, Lanfrancone $L$, et al. The Rlalpha subunit of protein kinase A (PKA) binds to Grb2 and allows PKA interaction with the activated EGF-receptor. Oncogene 1997;14:923-8.

41. Ciullo I, Diez-Roux G, Di Domenico M, Migliaccio A, Avvedimento EV. CAMP signaling selectively influences Ras effectors pathways. Oncogene $2001 ; 20: 1186-92$.

42. Myklebust JH, Josefsen D, Blomhoff HK, Levy FO, Naderi $\mathrm{S}$, Reed JC, et al. Activation of the CAMP signaling pathway increases apoptosis in human B- precursor cells and is associated with downregulation of $\mathrm{Mcl}-1$ expression. J Cell Physiol 1999;180:71-80.
43. Maquat LE. When cells stop making sense: effects of nonsense codons on RNA metabolism in vertebrate cells. RNA 1995; 1:453-65.

44. Clegg CH, Correll LA, Cadd GG, McKnight GS. Inhibition of intracellular CAMP-dependent protein kinase using mutant genes of the regulatory type I subunit. J Biol Chem 1987;262:13111-9.

45. Sandrini F, Kirschner LS, Stratakis C. Assessment of protein kinase A subunit expression in normal adrenal cortex and primary pigmented adrenocortical disease (PPNAD) and cell lines from patients with and without Carney complex (CNC) and PRKARIA mutations. The Endocrine Societies' 83't Annual Meeting-Denver-CO 2001.

46. Robinson-White A, Hundley TR, Shiferaw M, Bertherat J, Sandrini $F$, Stratakis CA. Protein kinase-A activity in PRKARIA-mutant cells, and regulation of mitogen-activated protein kinases ERK1/2. Hum Mol Genet 2003; 12:1475-84.

47. Sandrini F, Bertherat J, Rosenberg D, Matyakhina L, Groussin L, Bei T, et al. Effectors of tumorigenicity in primary pigmented nodular adrenortical disease (PPNAD): Protein kinase-A (PKA) subunit expression and activity, laser-capture microdissection (LCM) for $\mathrm{LOH}$ and CREB phosphorylation. The Endocrine Societies' 84th Annual Meeting - San Francisco - CA 2002.

48. Bertherat J, Groussin L, Sandrini F, Matyakhina L, Bei T, Stergiopoulos $S$, et al. Molecular and functional analysis of PRKARIA and its locus (17q22-24) in sporadic adrenocortical tumors: $17 q$ losses, somatic mutations, and protein kinase $\mathrm{A}$ expression and activity. Cancer Res 2003;63:5308-19.

49. Rosenberg D, Groussin L, Bertagna X, Bertherat J. CAMP pathway alterations from the cell surface to the nucleus in adrenocortical tumors. Endocr Res 2002;28:765-75.

50. Sandrini F, Kirschner LS, Sarlis NJ, Gimm O, Eng C, Stratakis CA. Loss-of-heterozygosity of the 17q22-24 chromosomal region and mutations of the gene encoding the protein kinase A type I-A regulatory subunit (PRKARIA) in sporadic thyroid tumors. 83rd Endocrine Society Meeting 2001; P3-565.

51. Kaltsas GA, Kola B, Borboli N, Morris DG, Gueorguiev M, Swords FM, et al. Sequence analysis of the PRKARIA gene in sporadic somatotroph and other pituitary tumours. Clin Endocrinol (Oxf) 2002;57:443-8.

52. Gordge PC, Hulme MJ, Clegg RA, Miller WR. Elevation of protein kinase $A$ and protein kinase $C$ activities in malignant as compared with normal human breast tissue. Eur J Cancer 1996;32A:2120-6.

53. Kjellman $M$, Kallioniemi OP, Karhu R, Hoog A, Farnebo LO, Auer $G$, et al. Genetic aberrations in adrenocortical tumors detected using comparative genomic hybridization correlate with tumor size and malignancy. Cancer Res 1996;56:4219-23.

\section{Endereço para correspondência:}

Fabiano Sandrini

Unidade de Endocrinologia Pediátrica

Universidade Federal do Paraná

R. Pe. Camargo 250

80060-240 Curitiba, PR

e-mail: fsandrini@globo.com 